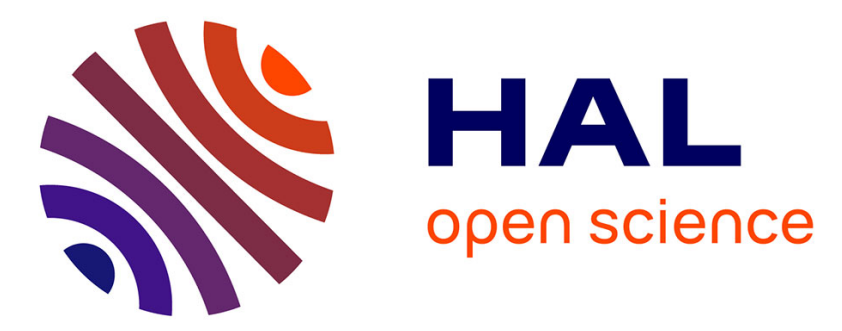

\title{
Effect of seeders and tillage equipment on vertical distribution of oilseed rape stubble
}

Olivier Schneider, Jean Roger-Estrade, Jean-Noël Aubertot, Thierry Doré

\section{To cite this version:}

Olivier Schneider, Jean Roger-Estrade, Jean-Noël Aubertot, Thierry Doré. Effect of seeders and tillage equipment on vertical distribution of oilseed rape stubble. Soil and Tillage Research, 2006, 85 (1-2), pp.115-122. 10.1016/j.still.2004.12.007 . hal-01354930

\section{HAL Id: hal-01354930}

https://hal-agroparistech.archives-ouvertes.fr/hal-01354930

Submitted on 20 Aug 2016

HAL is a multi-disciplinary open access archive for the deposit and dissemination of scientific research documents, whether they are published or not. The documents may come from teaching and research institutions in France or abroad, or from public or private research centers.
L'archive ouverte pluridisciplinaire HAL, est destinée au dépôt et à la diffusion de documents scientifiques de niveau recherche, publiés ou non, émanant des établissements d'enseignement et de recherche français ou étrangers, des laboratoires publics ou privés.

\section{(이)(\$)}

Distributed under a Creative Commons Attribution - NonCommercial - NoDerivatives| 4.0 
DOI: 10.1016/j.still.2004.12.007

\title{
Effect of seeders and tillage equipment on the vertical distribution of oilseed rape stubble
}

\author{
Olivier Schneider, Jean Roger-Estrade, Jean-Noël Aubertot*, Thierry Doré \\ UMR d'Agronomie INRA/INA P-G, BP 01, 78850 Thiverval-Grignon, France \\ *Corresponding author: aubertot@grignon.inra.fr
}

\section{Abstract}

When the spreading of a disease depends on the proportion of infected residues remaining at soil surface it is of crucial importance to analyse the effects of tillage practices on the vertical distribution of stubble. This is for instance the case with phoma stem canker (blackleg), whose epidemics are initiated in autumn, by air-borne ascospores released from stubble located at the soil surface. In this experiment, we compared the initial vertical distribution of oilseed rape residues to those observed after sowing and various tillage operations (rotary harrowing, stubble disking, chiseling and mouldboard ploughing). Results show that almost $20 \%$ of the initially buried residues was brought back to soil surface. Rotary harrow brought $40 \%$ of the residues buried in the $0-10 \mathrm{~cm}$ layer up to the surface and left unburied about $70 \%$ of the surface residues. Stubble disking appeared to be more efficient for residues burial than chiselling. Finally mouldboard plough was the only tool which buried all the residues. The results were used to develop a simple model that predicts the burial and the return to the soil surface of potentially infected residues as a function of the tillage practices used after harvest. 
Simulation of the effects of different tillage sequences showed that the order in which tools were used also affected the location of residues. Our results highlighted the importance of tillage in the cultural control of phoma stem canker and will contribute to the definition of Integrated Pest Management strategies for oilseed rape.

5

Key words: Integrated Pest Management - cultural control - conventional tillage - conservation tillage - Leptosphaeria maculans - Brassica napus. 


\section{Introduction}

When caused by a fungus, the spreading of a disease often depend on the proportion of the residues from the preceding crop left at the soil surface. This is the case for instance with phoma stem canker or blackleg, whose causal fungus is Leptosphaeria maculans, asexual stage Phoma lingam. It is one of the most severe disease damaging oilseed rape crops ( Brassica napus $)$ worldwide. This disease occurs in the main growing areas (Australia, Canada and Europe) and can result in major yield losses (Hall, 1992; West et al., 2001). Soil tillage should improve the control of the

10 pathogen if proper stubble management reduces the risk of contamination in the spreading area (Alabouvette and Brunin, 1970; Kharbanda and Tewari, 1996; Leake, 2000). Epidemics are initiated in autumn by the primary inoculum, i.e. ascospores produced on infected residues. These ascospores that can be spread over several kilometres by wind only appear if the infected debris are totally or partially exposed to solar radiation (Lacoste, 1963). Spores can develop on the residues of previous rape crops, when residues are left on the soil surface or brought back to the soil surface by tillage.

Thus, to prevent the development of this disease, stubble management by tillage should examine: (i) the effect of tillage and sowing on residue burial, especially that of stems, which are usually chopped and represent the main residual biomass after harvest and (ii) the effect of tillage and sowing on the return to the soil surface of residues from the $0-10 \mathrm{~cm}$ soil layer. Indeed, this layer is the most intensively tilled, due to stubble breaking, seed bed preparation and sowing. These residues in the $0-10 \mathrm{~cm}$ layer are 
either previously buried residues or the upper part of the main roots that are located at this level after harvest. The roots are particularly dangerous because they are the main long-term support for the mycelium, as their high lignin content renders them highly resistant to decomposition (Alabouvette and Brunin, 1970; McNish, 1979; Turkington

5 et al., 2000b). Thus, both burial and rising to the soil surface should be taken into account when evaluating the effect of tillage. These two processes may explain the conflicting effects of tillage on the risk of ascospore production sometimes reported in the literature. For instance, mouldboard ploughing limits sporulation by incorporating most of the surface residues into the soil and by increasing their decomposition rate

10 (Turkington et al., 2000a). However, ploughing may also induce ascospore production by bringing buried residues back to the soil surface (Turkington et al., 2000b).

Conventional tillage with mouldboard ploughing is being replaced by conservation tillage (where tillage is reduced or suppressed) in many countries. This means that a smaller proportion of surface residues are buried, but this proportion 15 depends on the type of tool used (disks or tines, fixed or not). Furthermore, sowing practices can also modify the location of residues in the soil, near the sowing line.

In this paper, we present the results of a field experiment carried out to analyse the effect of different types of soil tillage on the proportion of surface residues buried and the proportion of residues located in the $0-10 \mathrm{~cm}$ layer that rose up back to the 20 surface. For this, we used coloured residues to follow the movement of potentially infected residues in the soil. The results were used to design a simple model of transfer between the two soil compartments: surface and 0-10 cm. 


\section{Materials and methods}

\subsection{Site characteristics}

In October 2002, a field experiment was carried out at the INRA Experimental Station at Grignon, Yvelines $\left(1^{\circ} 58^{\prime} \mathrm{E}, 48^{\circ} 51^{\prime} \mathrm{N}\right)$ in the western Paris region on a silt 5 loamy Calcic Cambisol soil (FAO classification; texture of the 0-30 $\mathrm{cm}$ horizon: clay $29 \%$, silt $61 \%$ and sand $10 \%$; bulk density: $1.5 \mathrm{~g} . \mathrm{cm}^{-3}$ ).

\subsection{Experiment characteristics}

The method used was derived from studies dealing with the effects of soil tillage on the location of weed seeds (Cousens and Moss, 1990; Colbach et al., 2000) or the vertical distribution of cereal straw (Staricka et al., 1991) in the soil. The residues used in this study were $5 \mathrm{~cm}$ long pieces of the main stem of mature oilseed rape plants.

The studied tools were: drill seeder, rotary harrow, stubble disk, chisel and mouldboard plough. The main characteristics of these tools are presented in Table 1. The experiment was a randomised block design with three replications. However, in each block, tillage operations involving mouldboard ploughing were located side by side due to practical constraints. This was taken into account in the statistical treatment of the data. The size of each elementary plot was $3 \times 30 \mathrm{~m}^{2}$. Within each experimental plot, we delimited observation quadrats $\left(1 \times 2 \mathrm{~m}^{2}\right)$. Residues, sprayed with fluorescent paint to facilitate their recovery, were located either at the soil surface or in the $0-10 \mathrm{~cm}$

20 layer of each quadrat. We placed 20 red pieces horizontally on the soil surface and half buried 20 other red pieces. We considered all residues that were at least partly visible to be surface residues. We placed 20 blue pieces in the $0-10 \mathrm{~cm}$ soil layer $(5$ at $2.5 \mathrm{~cm}, 5$ at $5 \mathrm{~cm}, 5$ at $7.5 \mathrm{~cm}$ and 5 at $10 \mathrm{~cm}$ ), such that no part was visible at the soil surface. These 
buried residues were located in five $7.5 \mathrm{~cm}$-wide holes per replication. These holes were regularly distributed across the diagonal axis of the observation quadrat. The total number of residues used for this experiment was 900: 5 tool x 3 replications x (5 holes $\mathrm{x}$ 4 buried residues +40 residues at soil surface).

The stubble disk, chisel and mouldboard plough were directly used on untilled soil. Conversely, the soil had to be prepared for the other tools to be used in normal conditions. Thus mouldboard ploughing was performed before rotary harrowing and mouldboard ploughing followed by rotary harrowing was performed before seeding. The residues were placed just before the last tool was used. At the same time, the mean

10 soil water content of the $0-30 \mathrm{~cm}$ horizon was gravimetrically determined in each plot. During tillage operations, the mean soil water content was $0.16 \mathrm{~g} . \mathrm{g}^{-1}$. After the last tillage or seeding, the working depth of each tool in each treatment was controlled, and the colour and the new vertical location of the individual oilseed rape fragments were recorded. The final vertical position of buried residues was determined by measuring

15 the depth of the centre of the residue to the average soil surface. The percentage of the total amount of oilseed rape residues located in each $2.5 \mathrm{~cm}$ layer between the soil surface and a depth of $30 \mathrm{~cm}$ was calculated. Transfer parameters between two vertical compartments were calculated by taking the average percentage of each type of residue recovered in the $0-10 \mathrm{~cm}$ soil layer and at the soil surface, for the three replications with each tool.

\subsection{Statistical analysis}

Statistical analysis was carried out using the SAS software (SAS Institute Inc., 1990). For each treatment, we calculated the mean percentage of residues recovered at 
the soil surface and in the $0-10 \mathrm{~cm}$ layer (a very small number of them were not recovered); $95 \%$ confidence intervals were calculated. Transfer coefficients, which represent the proportions of residues that changed vertical compartment, were deduced from these percentages. As the treatment was not totally randomised, we tested residuals 5 independence with the Durbin-Watson test on the studied variables (Bergonzini, 1995). Considering the range of variation of the results, data were transformed using the arcsin transformation (Gomez and Gomez, 1984) before carrying out analysis of variance on the whole dataset using the GLM procedure. The differences between treatments were tested using the Student-Newman-Keuls test $(\mathrm{p}=0.05)$. 


\section{Results}

\subsection{Movement of residues to the soil surface}

The origin of surface residues depended on the tillage method used. The

5 mouldboard plough was the only tool that did not bring any residue from the $0-10 \mathrm{~cm}$ layer up to the surface (Fig. 1a). The rotary harrow brought $40 \%$ of the buried residues up to the soil surface. The seeder brought back nearly $20 \%$ of the initially buried residues. The chisel and stubble breaker brought up similar proportions of buried residues ( $\mathrm{ca}$ 15\%), even though the working depth of the chisel was greater $(18 \mathrm{~cm})$ 10 than that of the stubble breaker $(8 \mathrm{~cm})$.

\subsection{Burial of residues}

Burial efficiency also differed from one tool to another (Fig. 1b). The chisel and stubble breaker left similar amounts of residues at the soil surface. Rotary harrowing left $70 \%$ of the surface residues at soil surface. Sowing left almost all the residues at the

15 soil surface. As expected, ploughing buried all the surface residues. Mouldboard ploughing led to the deepest residue position (down to $30 \mathrm{~cm}$ ) and led to the distribution of residues throughout the whole soil profile (Fig. 2). Very few residues were buried less deep than $15 \mathrm{~cm}$ and none were buried above $5 \mathrm{~cm}$; most were located between 15 and $27.5 \mathrm{~cm}$. 


\subsection{Vertical distribution of residues buried by superficial tillage tools}

The vertical distribution of residues within the soil profiles differed among the three superficial tillage tools. The chisel (Fig. 3a) buried residues at a maximum depth

5 of $10 \mathrm{~cm}$. Most of the residues were found between 0 and $7.5 \mathrm{~cm}$ of depth, even though the working depth of the chisel was $18 \mathrm{~cm}$. The stubble breaker (Fig. 3b) buried residues between 0 and $10 \mathrm{~cm}$. This tool distributed the residues in the whole tilled layer $(0-8 \mathrm{~cm})$, and some of them were found slightly deeper than the working depth. Very few residues were found in the upper layer $(0-2.5 \mathrm{~cm})$. The rotary harrow (Fig. 3c) left

10 the largest proportion of the residues at the surface and buried the others very superficially, mostly between 0 and $7.5 \mathrm{~cm}$ of depth. Sowing (Fig. 3d) buried very few residues.

\subsection{Simulations}

Tillage tools are often combined in usual crop management sequences after 15 harvesting oilseed rape. To simulate the effects of successive use of tillage tools, we determined the transfer coefficients (Table 2) using the results presented in Fig. 1 and 2. As the proportions of residues buried or moved up were not significantly different for chisel and stubble breaker, the same parameters were chosen for these two tools. The simulated effects of various sequences on residue burial and movement are shown in Table 3.

Five tillage sequences were chosen for the simulations. Two of them comprised mouldboard ploughing followed either by stubble breaker/chisel or by rotary harrow before sowing. These sequences are frequent in conventional tillage after oilseed rape 
harvest. In the third sequence, only the stubble breaker or chisel was used (two passages) before sowing. The fourth and fifth sequences combined the stubble breaker or chisel and the rotary harrow. The latter three sequences reflect the diversity of the soil management sequences used by farmers practising conservation tillage. The sequences including mouldboard ploughing (sequences 1 and 2) were the most efficient at deep residue burial and at preventing the movement of residues to the surfact during secondary tillage. The sequence without the rotary harrow (sequence 3) resulted in a high proportion of the surface residues buried in the $0-10 \mathrm{~cm}$ layer $(41 \%)$ and the movement of only $19 \%$ of the residues initially located in the $0-10 \mathrm{~cm}$ layer to the soil

10 surface. The effect of the sequences including the rotary harrow differed depending on whether this tool preceded (sequence 4) or followed (sequence 5) the chisel: in the first case, a lower proportion of surface residues was left at soil surface and a higher proportion of the $0-10 \mathrm{~cm}$ residues were left in this layer.

\section{Discussion}

In this experiment where the conditions (speed, working depth, soil water content) closely reflected those encountered in the area for the rapeseed cropping, the implication of tillage on the vertical distribution of residues was found to differ considerably according to the tool used. This, consequently, has a pronounced effect on the spreading of diseases caused by fungus, like phoma stem canker. $(27 \mathrm{~cm})$ and the action of the skim coulter (Roger-Estrade et al., 2001). Furthermore, mouldboard ploughing buried all the surface residues deep within the tilled layer. Most 
residues were buried at more than $10 \mathrm{~cm}$ of depth, the highest proportion was buried in the $20-22.5 \mathrm{~cm}$ layer (almost 25\%) and none were buried in the most superficial layers $(0-5 \mathrm{~cm})$. Thus, even when followed by secondary tillage, mouldboard ploughing can efficiently prevent further phoma infection from surface residues and superficially 5 buried residues.

Conversely, the rotary harrow brought back a large proportion of residues to the surface, probably because of the vigorous mixing action of this tool. It is possible that the rotary harrow sorts soil and residues. After being hit by the tool, the residues, which are lighter than soil, land on the surface when falling back to the soil. Although the 10 chisel and stubble breaking disk have different working depths, they brought the same proportion of residues back to soil surface. Seeding brought up a large proportion of the more superficially buried residues. Furthermore, the rotary harrow was poorly efficient at residue burial. This tool is appreciated for its fragmentation action, but appears to be very dangerous as it brought back a large proportion of residues to the surface, thus 15 enhancing the production of phoma stem canker primary inoculum.

Stubble breaking and the chisel are known to exert a less efficient fragmentation action on the soil. These tools buried a greater proportion of residues than the rotary harrow, with a slight advantage for stubble breaking as it left very few residues between 0 and $2.5 \mathrm{~cm}$. Thus, stubble disking and the chisel should be preferred to the rotary 20 harrow when trying to prevent sporulation.

Our results also showed that the seeder affects the location of residues, increasing the risk of bringing superficially buried residues back to the soil surface. This is especially dangerous because these residues are exposed at the precise moment when the crop is the most sensitive to phoma disease. 
The importance of tillage on crop residue management was outlined by different authors (Guérif et al., 2001). Similar effect of the chisel was observed (Colvin et al., 1986), decreasing of the surface residues proportion by $80 \%$. Conversely, a more pronounced effect of the seeder in bringing back buried residues at soil surface. This 5 was probably due to the type of tool used. Indeed, there is a great variety between seeder types and their effects on residue location need to be further investigated.

Others experiments gave similar results on the vertical distribution of coloured tracers (ceramic spheres or polyethylene chips) or oat residues (Staricka et al., 1991; Allmaras et al., 1996). In these studies the tracers or residues were incorporated by 10 mouldboard ploughing down $27-30 \mathrm{~cm}$ depth and by disk or chisel below $10 \mathrm{~cm}$ with a general pattern of distribution in the soil similar to the one obtained in our experiment.

The robustness of the results obtained in this study needs to be further explored. We propose to analyse the effects of the same tools in other soil conditions, where a different mechanical behaviour may modify the vertical distribution induced by tillage

15 and sowing. Despite these experimental drawbacks, tillage appears to be a very promising method for the control of phoma stem canker because it does not apply a selection pressure to the fungus as do fungicides or host resistance genes. Reducing the number of surface residues is an efficient way of reducing the pathogen population and limiting its sexual reproduction. Therefore, it is a good way of limiting the genetic 20 variability of the fungus. For these reasons, tillage control can reduce the adaptability of the fungus and thus can improve the durability of the genetic resistance of the rapeseed crops (Brun et al., 2001; McDonald and Celeste, 2002). Furthermore, Tox 0 phoma strains, recently identified as another species, Leptosphaeria biglobosa (Shoemaker and Brun, 2001; Mendes-Pereira et al., 2003), tend to be located in the upper part of the 
stem, whereas Tox + phoma strains tend to be located at the bottom of the stem and in the root. As tillage has different effects on the upper part of the stem (located at the soil surface) and on the roots (located in the $0-10 \mathrm{~cm}$ layer), the morphological repartition of phoma strains can be greatly modified by tillage, which can in turn modify the 5 ecological balance.

The results presented in this paper were used to develop a simple compartmental model that we used to simulate different tillage sequences. This model, which should be validated before being used to predict the locations of residues, was built with the sole aim of taking into account the effect of tool sequences. It does not take into account

10 residue decomposition rate. This rate decreases the mass of infected residues as a function of numerous parameters like residue size, roots or stem, soil nature (Turkington et al., 2000b). This aspect will have to be included in the model to improve risk assessment. Furthermore, the model did not integrate the movement of residues that were initially buried at more than $10 \mathrm{~cm}$, even though this is necessary to simulate the

15 effect of complex tool sequences. Nevertheless, our simulations showed that different tillage sequences have very different effects on the locations of residues. Conventional tillage appeared to be more efficient at preventing the spread of phoma than did superficial tillage. Thus, these results suggest that the choice of the tillage tools after rape harvest and the order of the sequence have a significant effect on the risk of 20 spreading phoma stem canker. 


\section{Acknowledgements}

The authors thank Jacques Troizier, Head of the Experimental Centre at Grignon, and his teams for conducting the field trials. The statistic assistance from Jean5 François Fourbet was greatly appreciate. The authors are also grateful to Beatrice Le Fouillen, Véronique Tanneau, Richard Gosse, Dominique Le Floch and Marc Klockiewicz for technical assistance. This work was financed by INRA and CETIOM.

\section{References}

10 Alabouvette, C. and Brunin, B., 1970. Recherches sur la maladie du colza due a Leptosphaeria maculans (desm.) ces. et de not. Rôle des restes de culture dans la conservation et la dissémination du parasite. Ann. Phytopathol. 2, 463-475.

Allmaras, R.R., Copeland, S.M., Copeland, P.J. and Oussible, M., 1996. Spatial relation beween oat residue and ceramic spheres when incorporated sequentially by tillage. Soil Sci. Soc. Am. J. 60, 1209-1216.

Bergonzini, J.-C.,1995. Analyse et planification des expériences. Les dispositifs en blocs. MASSON, Paris, 72-73.

Brun, H., Ruer, D., Levivier, S., Somda, I., Renard, M. and Chèvre, A.M., 2001. Presence in Leptosphaeria maculans populations of isolates virulent on resistance introgressed into Brassica napus from the B. nigra genome. Plant Pathol. 50, 69-74. 
Colbach, N., Roger-Estrade, J., Chauvel, B. and Caneill, J., 2000. Modelling vertical and lateral seed bank movements during mouldboard ploughing. Eur. J. Plant Pathol. 13, 111-124.

Colvin, T.S., Berry, E.C., Erbach, D.C. and Laflen, J.M., 1986. Tillage implement effects on corn and soybean residue. Transactions of the ASAE. Am. Soc. Agric. Eng. 29, 56-59.

Cousens, R. and Moss, S.R., 1990. A model of the effects of cultivation on the vertical distribution of weed seeds within the soil. Weed Res. 30, 61-70.

Gomez, K.A. and Gomez, A.A., 1984. Statistical procedures for agricultural research. Wiley and Sons, New York, 680 pp.

Guérif, J., Richard, G., Dürr, C., Machet, J.M., Recous, S. and Roger-Estrade, J., 2001. A review of tillage effects on crop residue management, seedbed conditions and seedling establishment. Soil Till. Res. 61, 13-32.

Hall, R., 1992. Epidemiology of blackleg of oilseed rape. Can. J. Plant Pathol. 14, 4655.

Kharbanda, P.D. and Tewari, J.P., 1996. Integrated management of canola diseases using cultural methods. Can. J. Plant Pathol. 18, 168-175.

Lacoste, L., 1963. Action de la température et de l'éclairement sur la reproduction en culture pure de diverses espèces du genre Leptosphaeria Ces. et de Not. C. R. Acad. Agric. Fr., 2668-2671.

Leake, A., 2000. The development of integrated crop management in agricultural crops: comparisons with conventional methods. Pest Manag. Sci. 56, 950-953.

McDonald, B.A. and Celeste, L., 2002. The population genetics of plant pathogens and breeding strategies for durable resistance. Euphyt. 124, 163-180. 
McNish, G.C., 1979. Survival of Leptosphaeria maculans in rapeseed root tissue. Aust. Plant Pathol. 8, 23-24.

Mendes-Pereira, E., Balesdent, M.H., Brun, H. and Rouxel, T., 2003. Molecular phylogeny of the Leptosphaeria maculans-L. biglobosa species complex. Mycol. Res. 107, 1287-1304.

Roger-Estrade, J., Colbach, N., Leterme, P., Richard, G. and Caneill, J., 2001. Modelling vertical and lateral weed seed movement during mouldboard ploughing with a skim-coulter. Soil Till. Res. 63, 35-49.

SAS Institute Inc., 1990. SAS/STAT User's Guide. Version 6, fourth ed. Cary, NC, USA. SAS/STAT User's Guide. Version 6, fourth ed. Cary, NC, USA.

Shoemaker, R.A. and Brun, H., 2001. The teleoporphe of the weakly aggressive segregate of Leptosphaeria maculans. Can. J. Bot. 79, 412-419.

Staricka, J.A., Allmaras, R.R. and Nelson, W.W., 1991. Spatial variation of crop residue incorporated by tillage. Soil Sci. Soc. Am. J. 55, 1668-1674.

15 Turkington, T.K., Clayton, G.W. and Woods, D.L., 2000a. The impact of soil incorporation of canola residues and stubble application of chemical on decomposition and inoculum production by Leptosphaeria maculans. Can. J. Plant Pathol. 22, 155-159.

Turkington, T.K., Clayton, G.W., Klein-Gebbinck, H. and Woods, D.L., 2000b. Residue decomposition and blackleg of canola: influence of tillage practices. Can. J. Plant Pathol. 22, 150-154.

West, J.S., Kharbanda, P.D., Barbetti, M.J. and Fitt, B.D.L., 2001. Epidemiology and management of Leptosphaeria maculans (phoma stem canker) on oilseed rape in Australia, Canada and Europe. Plant Pathol. 50, 10-27. 


\section{Tables and figures}

\section{TABLES}

\begin{tabular}{|c|c|c|c|c|}
\hline Code & $\begin{array}{c}\text { Tool } \\
\text { (manufacturer) }\end{array}$ & $\begin{array}{l}\text { Working } \\
\text { depth } \\
(\mathrm{cm})\end{array}$ & $\begin{array}{c}\text { Tool } \\
\text { characteristics }\end{array}$ & $\begin{array}{l}\text { Tractor } \\
\text { Speed } \\
\left(\mathrm{km} \cdot \mathrm{h}^{-1}\right)\end{array}$ \\
\hline$S$ & $\begin{array}{l}\text { Seeder } \\
\text { (Naudet) }\end{array}$ & 5 & $\begin{array}{c}21 \text { hooves } \\
\text { (Working width of } 3 \mathrm{~m} \text { ) }\end{array}$ & 6 \\
\hline $\mathrm{RH}$ & $\begin{array}{c}\text { Rotary } \\
\text { Harrow } \\
\text { (Howard) }\end{array}$ & 8 & $\begin{array}{c}12 \text { tine pairs } \\
\text { (Working width of } 3 \mathrm{~m} \text { ) }\end{array}$ & 3.5 \\
\hline SB & $\begin{array}{c}\text { Stubble } \\
\text { Breaker } \\
\text { (John Deere) }\end{array}$ & 8 & $\begin{array}{l}12 \text { carve disks in front and } \\
13 \text { smooth disks at the back } \\
\text { (Working width of } 2.3 \mathrm{~m} \text { ) }\end{array}$ & 6 \\
\hline C & $\begin{array}{l}\text { Chisel } \\
\text { (Duro) }\end{array}$ & 18 & $\begin{array}{l}11 \text { tines on } 3 \text { levels } \\
\text { (Working width of } 3 \mathrm{~m} \text { ) }\end{array}$ & 5 \\
\hline$P$ & $\begin{array}{l}\text { Mouldboard } \\
\text { Plough } \\
\text { (Huard) }\end{array}$ & 30 & $\begin{array}{l}2 \text { shares with a skim-coulter } \\
\text { (Working width of } 2 \times 0.35 \mathrm{~m} \text { ) }\end{array}$ & 4 \\
\hline
\end{tabular}

Table 1: Characteristics of the five tools used in the experiment. 


\begin{tabular}{ccccc}
\hline Tool & from S to $S$ & $\begin{array}{c}\text { from } S \\
\text { to } 0-10 \mathrm{~cm}\end{array}$ & $\begin{array}{c}\text { from } \\
0-10 \mathrm{~cm} \\
\text { to } \mathrm{S}\end{array}$ & $\begin{array}{c}\text { from } \\
0-10 \mathrm{~cm} \\
\text { to } 0-10 \mathrm{~cm}\end{array}$ \\
\hline SBC & 32 & 62 & 15 & 50 \\
$\mathrm{RH}$ & 78 & 21 & 45 & 37 \\
$\mathrm{~S}$ & 96 & 4 & 20 & 80 \\
$\mathrm{P}$ & 0 & 4 & 0 & 14 \\
\hline
\end{tabular}

Table 2: Transfer coefficients in percentage (S: surface); SB: stubble breaking, RH: rotary harrowing, C: chisel cultivating, S: sowing, P: ploughing.

\begin{tabular}{ccccccc}
\hline & \multicolumn{2}{c}{ Residues initially located at soil surface } & \multicolumn{4}{c}{$\begin{array}{c}\text { Residues initially located at 0-10 cm of } \\
\text { depth }\end{array}$} \\
\hline $\begin{array}{c}\text { Tillage } \\
\text { sequence }\end{array}$ & $\begin{array}{c}\text { \% left at } \\
\text { soil surface }\end{array}$ & $\begin{array}{c}\% \text { buried at } \\
\text { 0-10 cm buried } \\
\text { depth }\end{array}$ & $\begin{array}{c}\text { \% moved } \\
\text { deeper } \\
\text { than } 10 \mathrm{~cm}\end{array}$ & $\begin{array}{c}\text { \% left at } 0- \\
\text { to soil } \\
\text { surface }\end{array}$ & $\begin{array}{c}\text { \% buried } \\
\text { depth }\end{array}$ & $\begin{array}{c}\text { deeper } \\
\text { than } 10 \mathrm{~cm}\end{array}$ \\
\hline $\mathrm{P} / \mathrm{SBC} / \mathrm{S}$ & 1 & 2 & 97 & 3 & 6 & 91 \\
$\mathrm{P} / \mathrm{HR} / \mathrm{S}$ & 2 & 1 & 97 & 7 & 4 & 89 \\
$\mathrm{SBC} / \mathrm{SBC} / \mathrm{S}$ & 29 & 41 & 30 & 19 & 28 & 53 \\
$\mathrm{HR} / \mathrm{SBC} / \mathrm{S}$ & 39 & 48 & 13 & 28 & 38 & 34 \\
$\mathrm{SBC} / \mathrm{HR} / \mathrm{S}$ & 57 & 26 & 17 & 37 & 19 & 44 \\
\hline
\end{tabular}

Table 3: Percentage of oilseed rape residues buried, unchanged and brought back

10 to the soil surface following different combinations of tillage tools after an oilseed rape harvest. Codes for the tools: stubble breaking or chisel cultivating (SBC), rotary harrowing $(\mathrm{RH})$, sowing $(\mathrm{S})$ and ploughing $(\mathrm{P})$. 


\section{FIGURE CAPTIONS}

Figure 1: Percentage of the residues at the soil surface after using each of the five tools (a) percentage of the residues initially located in the $0-10 \mathrm{~cm}$ layer (b) percentage of the residues initially at the soil surface. SB: stubble breaking, RH: rotary harrowing, C: chisel cultivating, S: sowing, P: ploughing. Error bars are the $95 \%$ confidence intervals of the means observed in three replicates for each treatment. Bars

10 with the same letter are not significantly different $(p=0.05$, Student-Newman-Keuls test).

Figure 2: Location of surface residues (percentage) after burial by mouldboard ploughing with a skim coulter. Error bars are the $95 \%$ confidence intervals of the means

15 observed for three replicates. wd: working depth.

Figure 3: Stubble burial expressed as the percentage of total amount of residues originally at the surface in each $2.5-\mathrm{cm}$ layer from 0 to $30 \mathrm{~cm}$ of depth, after tillage with three common superficial tools (a: chisel cultivating, b: stubble breaking, c: rotary 20 harrowing) and after sowing (d). Error bars are the 95\% confidence intervals of the means for three replicates of each treatment. wd: working depth. 
FIGURES

5

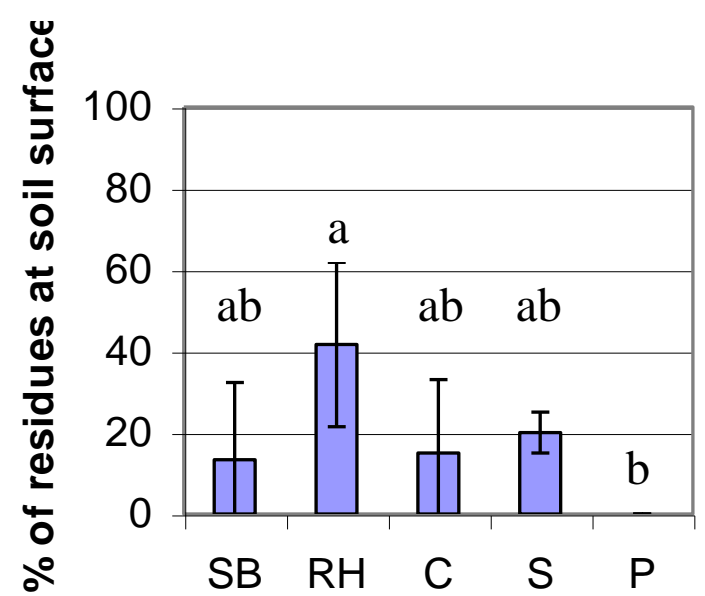

(a)

10

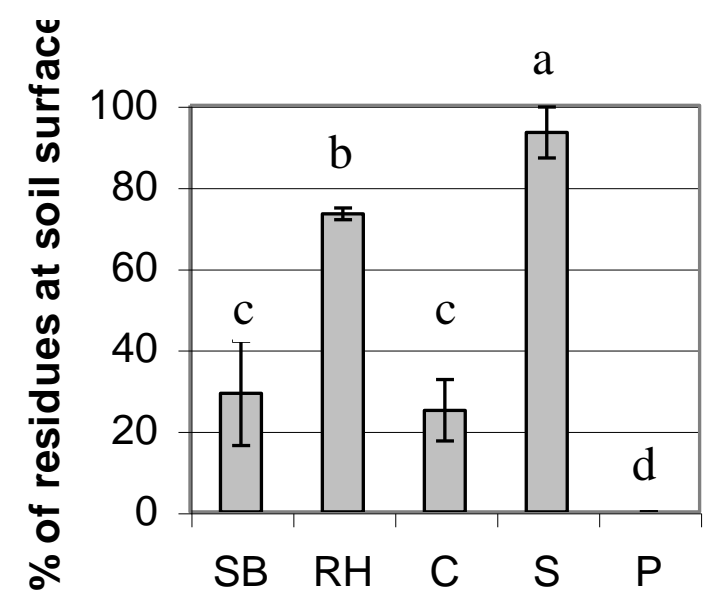

(b)

Figure 1 


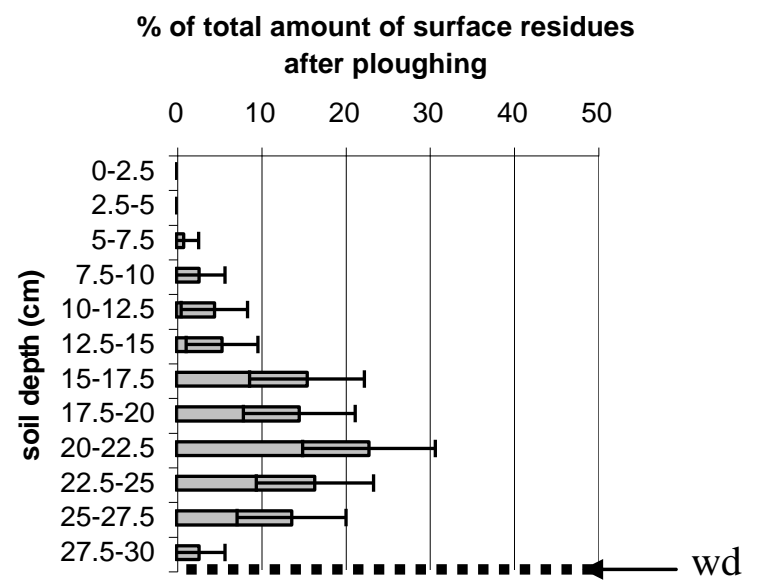

5

Figure 2 


\section{;}

(a) \% of total amount of surface residues after chisel cultivating

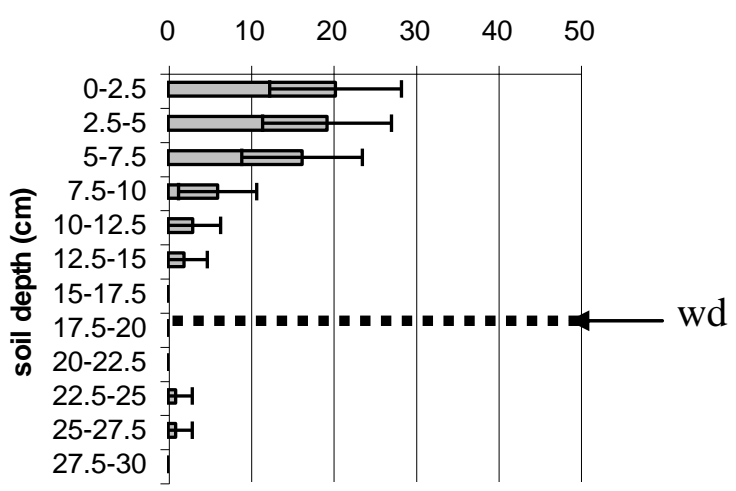

1

(c) \% of total amount of surface residues after rotary harrowing

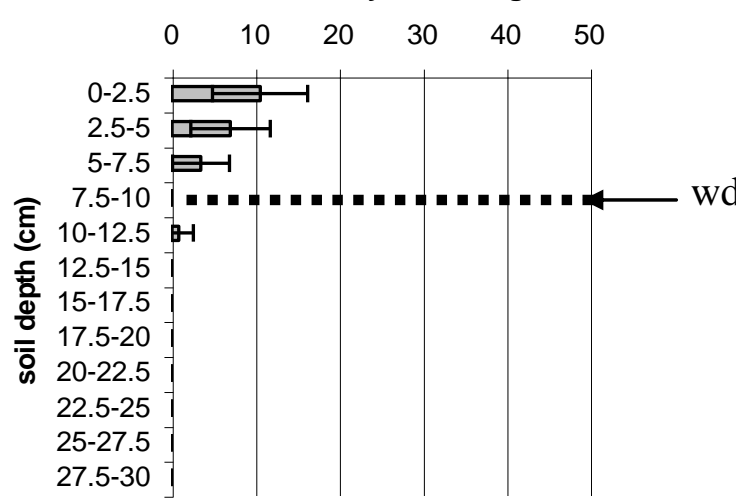

(b) $\%$ of total amount of surface residues after stubble disking

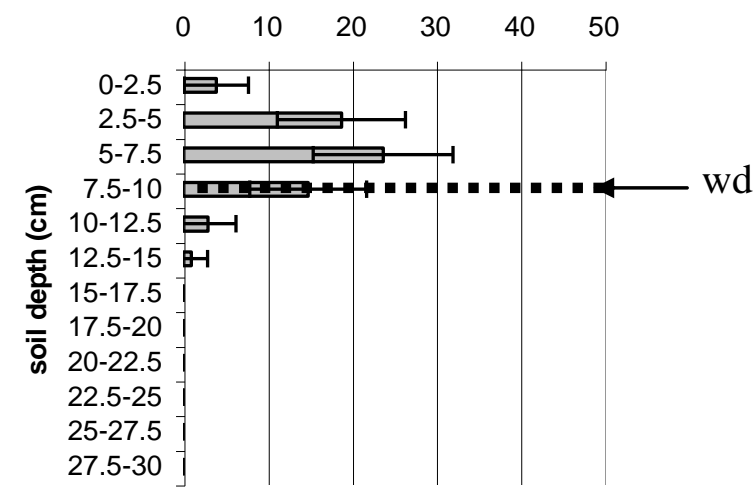

1

(d) $\%$ of total amount of surface residues after sowing

$\begin{array}{llllll}0 & 10 & 20 & 30 & 40 & 50\end{array}$

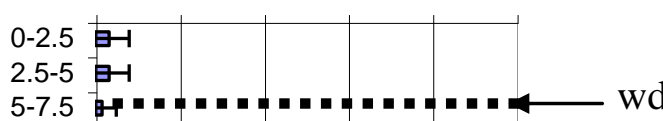

$7.5-10$

है $10-12.5$

12.5-15

के $15-17.5$

음 17.5-20

o $20-22.5$

22.5-25

25-27.5

27.5-30

Figure 3 